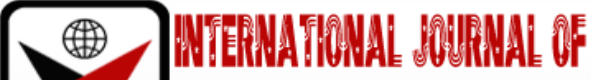

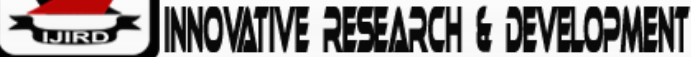

ISSN 2278-0211 (Online)

\section{Insights into Regenerative Paradigm in Cultural Heritage Sites: Lessons from Case Studies}

\author{
Samar El Nagar
Researcher, Department of Urban Design \& Planning, Ain Shams University, Egypt
Ghada Farouk
Professor, Department of Urban Design \& Planning, Ain Shams University, Egypt
Rowaida Rashed
Associate Professor, Department of Urban Design \& Planning, Ain Shams University, Egypt
}

\begin{abstract}
:
Conservation or rehabilitation can describe archaeological preservations of valuable resources that are at the risk of getting extinct. Today, rehabilitation exceeds just a celebration of historical icons. The everincreasing human demand in the urban heritages has encouraged the conservation and rehabilitation programs to be consistent with economic and social development, in fact going beyond sustainability towards being regenerative. This paper draws insights on the best practice approaches to conservation and rehabilitation of the heritage sites, having Mexico City and Fez, as a case study. This does not mean that the best practice approach is error-free or superior (Liu et al., 2019). It, however, shows which approach has several constraints and difficulties. As a result, this paper intends to provide analytical perceptions onto the rehabilitation and conservation program that took in Mexico City and Fez to identify the actions that can support being regenerative towards helping make future rehabilitation and conservation of heritage sites a success.
\end{abstract}

Keywords: Rehabilitation- regenerative design- sustainable paradigm- heritage management

\section{Introduction}

Managing cultural heritage site is an important tool towards sustaining cities. Although the planning theories that project the expected image of a city in the next three or four decades are not available today. Thus, instead of focusing on creating a long-term urban situation, planners are now inventing a less costly practice. This alternative involves understanding the current best practices and averts the errors and risks observed. These best practices should consider the arrays of the vast problems in each urban site where managing these sites were addressed through regenerative acts, going beyond sustainability. This paper discusses two best practice approaches to conservation and rehabilitation of the historic cities, Mexico City and Fez, as a case study. This does not mean that the best practice approach is error-free or superior (Liu et al., 2019). It, however, shows which approach has several constraints and difficulties. As a result, this paper intends identify the areas of strength and weaknesses, actions towards making future rehabilitation and conservation of heritage sites a success while promising for long term viability towards attaining Sustainable Development Goals.

\section{Going beyond Sustainability: Regenerative Development}

Regenerative Design is a stream of the Ecological framework where different aspects of the environment were considered along with the mitigation of the human. It is based on the evolution of the concept of sustainable and ecological approaches in sciences as per the below table 1 which shows the evolution of the sustainability paradigms till recent. Briefly, regenerative design was defined by (Mang\& Reed, 2012) as 'a system of technologies and strategies based on the understanding of the inner working of ecosystems that generates design to regenerate rather than deplete underlying life support systems and resources within socio-ecological wholes'. (Williams, 2000) further elaborates that the term 'regenerative' describes processes that restores, renew, or revitalize their own sources of energy and materials to create sustainable systems that integrate the needs of the society within nature as per the below figure (2-1) which shows the linear versus circular metabolism towards being regenerative. 


\begin{tabular}{|c|c|c|c|}
\hline Paradizm & Yean & Inflaraner & Paradifm \\
\hline Busclimulik achilntate & $1908-1968$ & Olgyey, Wriph, Neutra & Dimavary \\
\hline $\begin{array}{l}\text { Frvircamentel } \\
\text { archilocture }\end{array}$ & $1969-1972$ & Le Malleg & Hurmany \\
\hline $\begin{array}{l}\text { Energy consious } \\
\text { achilenture }\end{array}$ & $1923-1983$ & $\begin{array}{l}\text { AlA, Bulcowb, ASES, } \\
\text { PLA }\end{array}$ & $\begin{array}{l}\text { Energy } \\
\text { elliciency }\end{array}$ \\
\hline Sutuinuble urchitecture & $1984-1993$ & Brundilend, IIA, Feist & $\begin{array}{l}\text { Rewource } \\
\text { etficiency }\end{array}$ \\
\hline Green archintecture & $1993-2006$ & USGBC, Van der Ryz & Neutrality \\
\hline $\begin{array}{l}\text { Carbou aedind } \\
\text { archilexture }\end{array}$ & $2006-2015$ & UN IFCC, Marria & Resilienee \\
\hline Renenerative anchiliexture & 2016-Future & Lyk, Broungart, Benyus & Recouvery \\
\hline
\end{tabular}

Figure 1 Sustainability paradigms in Architecture in 20th and 21st Century-

Source:(Shady Attia Regenerative and Positive Impact Architecture Learning from Case Studies, 2018)

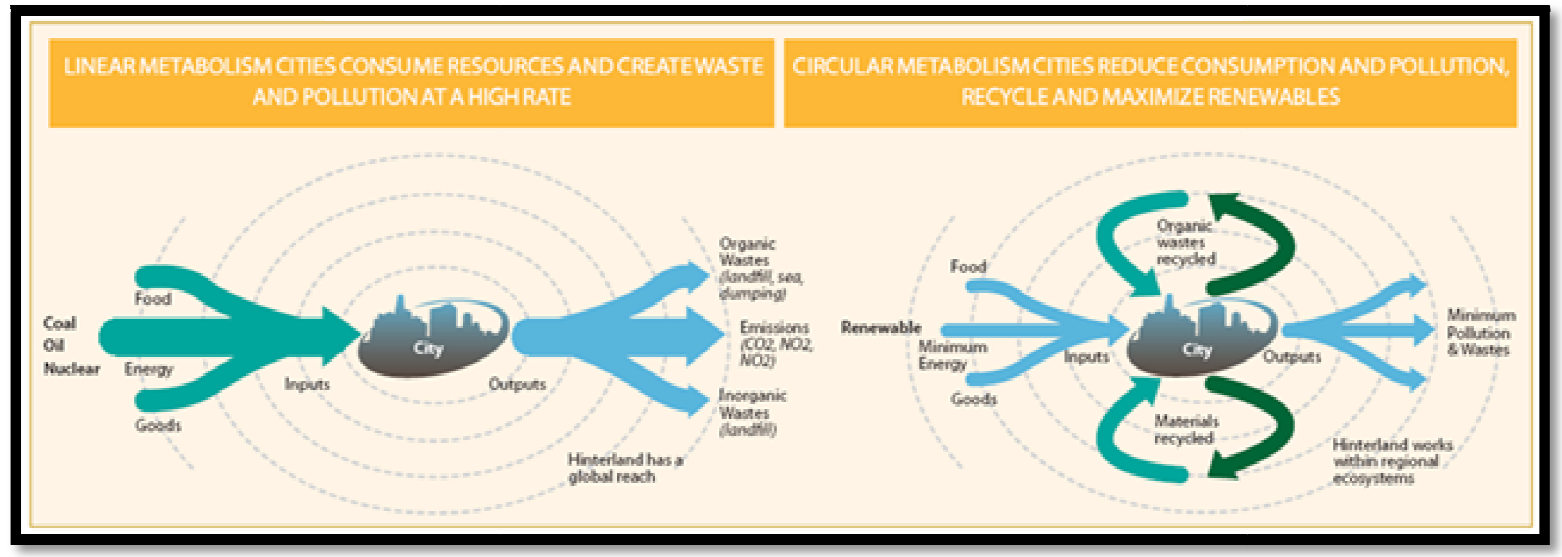

Figure 2: Linear versus circular metabolism

Source: Girardet, H. (2014). Creating Regenerative Cities.Creating Regenerative Cities. https://doi.org/10.4324/9781315764375

Hence, in regenerative design, the buildings are expected to act as 'catalysts' for positive change to support the mutual relationship between human in nature in place, where manmade systems are to be designed to produce more than they consume in areas as: water, carbon, materials, nutrients, etc.... This contributes to offsetting the negative environmental impact of the existing stock to better environmental performance and a resilient better environment in response to several changes, such as: climate change. The main aim of is to merge between people, buildings, and nature with an objective of regenerating the earth's ecosystem. The role of regenerative design becomes to determine the right phenomena to work on and to give form to direct regenerative design solutions that realizes the maximum potential and build a field of commitment in which stakeholders are seen as creators and ongoing overseers of these solutions (Mang and Reed, 2012).The regenerative design approach has six major benefits which are: environmental, economic, social, and human, resilience and democratic benefits. Each of these benefits are further classified in Woo's demonstration of the regenerative development in the World Future Council in 2014 (Woo, 2014).

\section{RegenerativeParadigm in Heritage Sites}

Being regenerative has been the interest on many fields including urban planners and designers. Thus, when tackling conservation acts in heritage sites, it becomes necessary to address the regenerative paradigm as a part of the process. Not only because of its benefits, but also it supports people to ensure that the participatory approach results in positive outcomes on economy, social, cultural, and environmental scopes. Moreover, it will help to create a loop that regenerates itself towards a healthy ecosystem and resilient environments in heritage sites.In fact, the human impacts were never neglected; however, some sustainable models did not consider the broader environments which resulted in a lag between user behavior and the way building/ space performance is expected to perform (Turner and Frankel, 2008). In this realm, urban heritage holds a lot of potentials to the future cities, where human / people's role becomes crucial when addressing any change in heritage sites as they are the influencers in double ways, consumers, and producers. Thus, any sustainable preservation of the heritage is obliged to include social and economic aspects of development in accordance with the human aspect (Aalund, 2005). In fact, being regenerative has become a necessity to face the current modern changes that takes place. Where there is a need to integrate human within all processes of sustainability

\section{Case Studies}

The following analysis will shed the lights on the regenerative paradigm in heritage sites and how can the used tools reflect positively not only on the heritage site realm, but also on the city level as well. Two case studies were chosen; one is international one in Mexico City, Historic Center of Mexico City and the second one is a regional example, Medina of Fez in Morocco. Each will be demonstrated stating three major points, highlights of the regenerative project, regenerative parameters tackled in the project and compliance of the results with the SDG's. The results are to generate action 
plansbecause of the comparative case studies analysis towards supporting economy, social and cultural activities and environmental benefits while mitigating human as a core element in the process.

\subsection{Historic Center of Mexico City}

\subsubsection{Highlightsof the Project}

The site was inscribed as a World heritage site in 1981. The development project is classified as urban regeneration through mixed use of historic buildings where the process achievements is remarkable on social, cultural, and physical levels of sustainability. The objectives of the program in hand are to conserve and revitalize the most historically important area of the city, save, and adapt abandoned heritage buildings, invest in physical fabric, and build middle-income employment where these changes took place after the deterioration and the abandonment of its population due to the earthquake of 1985 which revived the historic center. The program took a multi-sector approach where public works and incentives, private investment, charity, and civil society participation are all examples of publicprivate partnerships that participated in the program. The citizens laid the foundation for regeneration process back in 1980's and 1990's taking into consideration the World Heritage status of the site. Yet, they did not have the motivation and fund. By the 2000's, national public sector along with private ones (business leader) and private sectors set up the nonprofit Fundación del Centro Histórico, which led programming, and the SociedadInmobiliaria del Centro Histórico which managed private renowned monuments, and the early efforts of citizen groups in the 1980s and 1990s laid the groundwork for regeneration but did not have therequired impetus. Then, at the turn of the millennium, public-sector leadership at the national and city level converged and the prominent business leader-Carlos SlimHelú-was hired by the President to lead the effort. He set up twofold governance structure entity including the non-profit Fundacióndel Centro Histórico, oversaw programming and the SociedadInmobiliaria del Centro Histórico oversaw private real estate acquisition and reconstruction.Click or tap here to enter text.(Case Studies in Heritage Regeneration by Cultural Heritage Finance Alliance - CHiFA - Issuu, n.d. Historic Center of Mexico City, Mexico - Issuu, n.d.)This integrated multi-sector approachresulted in a wide spectrum of impacts along with contributions from intellectuals and professional leaders. The hereafter figure (4-1) shows a view of the Historic city center after the process.

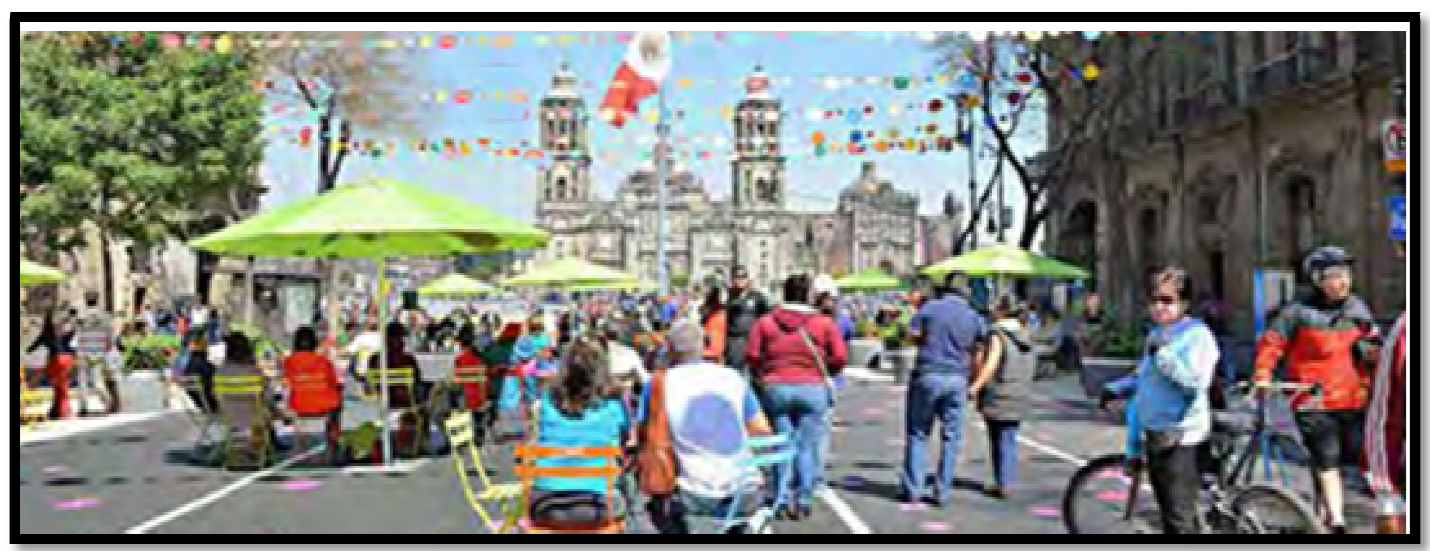

Figure 3: View of Historic City center after the process

Source:(Case Studies in Heritage Regeneration by Cultural Heritage Finance Alliance - CHiFA - Issuu, 2021)

The conditions of the historic center of Mexico have changed substantially from being a hub for artisans, intellectual and commercial life to being a hub of crimes nevertheless the degrading in population level resulting in financial degrading. Being followed by an earthquake in 1985 which negatively affected most of the historical buildings. All these parameters have been regeneratively approached where the site has flourished by creating opportunities.

\subsubsection{Regenerative Parameters within the Project}

The campaign greatly improved the region of the impacted area, the size and number of buildings conserved, reoccupied, and adapted, and the amount of digital and traditional infrastructure modernized as referred to in figure (4-2) (Torres-Lima et al., 2018). It was also vital for improving quality of life in Mexico Citythrough, public safety improvement,increased job opportunities created through permanent business and works undertaken-large and improved public services and security ( (Case Studies in Heritage Regeneration by Cultural Heritage Finance Alliance CHiFA - Issuu, n.d.-a)such as:

- family integration, health, and education.

- removal of commercial signs, repaired sidewalks, relocation of street vendors, new buried fiber optic cables, and pedestrianizing streets.

- Cultural activities and public events to attract visitors

- Improved public transportation and the establishment of bicycle lanes.

- $\quad$ Restoration of monuments and public spaces 
In fact, the conservation program that helped to achieve represents an excellent example to cities aiming for a regeneration program.

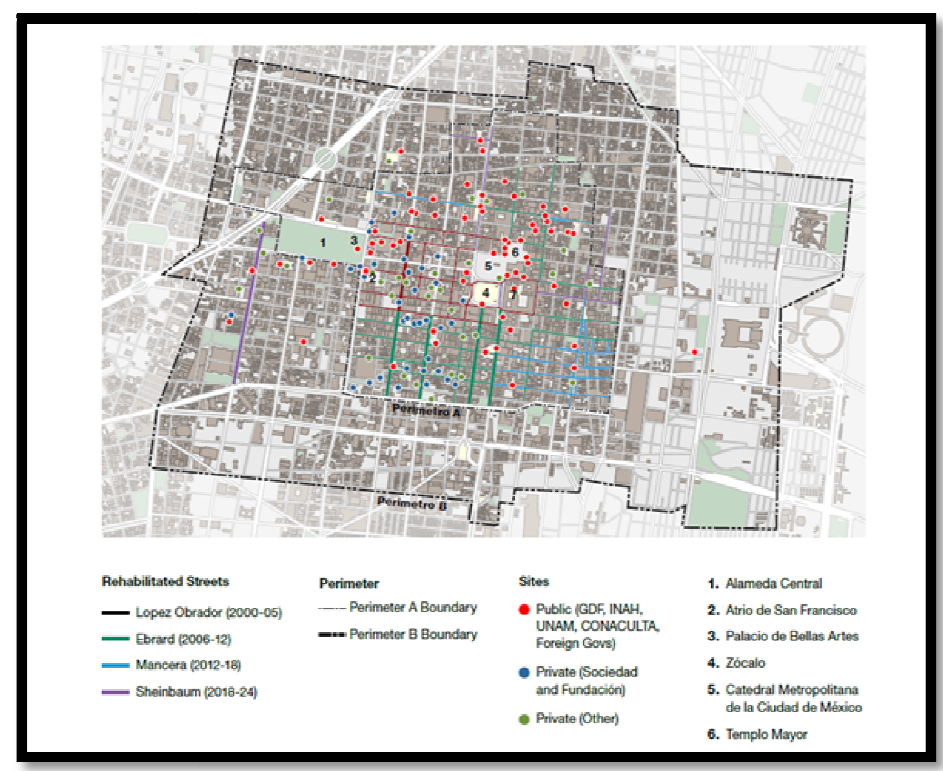

Figure 4: Map of the Restored and Upgraded Streets And Sites in the Historic City Center of Mexico Source: (Case Studies in Heritage Regeneration by Cultural Heritage Finance Alliance - Chifa - Issuu, 2021)

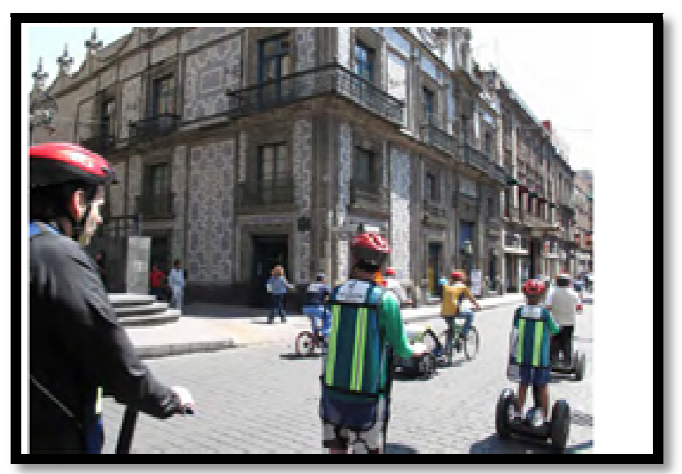

Figure 5: One of the Upgrades Avenues Showing Different Lanes, Activities and Public Safety Employed Source: (Historic Center Of Mexico City, Mexico - Issuu, 2021)

On a social level, the council Complementary social programs focused on family integration, homelessness, education, public safety, and health with minimal residential displacement and the formulation of an integrated strategy aim at improving property values. Economically, the SociedadInmobiliaria Del Centro Historica raised private investment for the restoration, adaptive, and purchase reuse of buildings in the targeted zones (Roders\&Bandarin, 2019).

\subsubsection{Complying Sdg's (Sustainable Development Goals)}

Dynamic private engagement and political leadership characterized the success of the rehabilitation project in this historic city of Mexico. The rehabilitation program of Mexico City positively impacted the UN Sustainable Development Goals where the following provides a sense of significant impacts (Guilbaud et al., 2021).

- Fundación Centro Histórico's social programs aimed at ending poverty in its all form

- Fundación Centro Histórico's social programs established two Family Integration to promote well-being and ensure healthy lives for all ages.

- With the support of the Secretary of Education, $\mathrm{FCH}$ developed a pilot program to promote lifelong learning opportunities and ensure equitable and inclusive quality education for all.

\subsection{Medina of Fez, Morocco}

\subsubsection{Highlights of the Project}

The development program is classified as development finance for poverty alleviation through heritage regeneration where the program main objective is regenerating historic buildings, improve access through traffic flow, infrastructure, safety and wellbeing, and institutional strengthening which are all examples of urban regeneration and improved quality of life. The World / International Bank for Reconstruction and Development has focused on the medina of Fez as part of its millennial program where more than half of the historic Medina's 13,000 structures were in danger of collapsing wherethe physical environment was identified as a major contributor to the city's continuing decline in wellbeing and economic opportunity. The World Bank's \$14.3 million loan program in 1998 provided an incentive for national 
and local organizations to collaborate to solve both physical and social problems. Residents were the focus of the initiative, and they were involved in project surveys, conservation techniques training, and restoration work(Case Studies in Heritage Regeneration by Cultural Heritage Finance Alliance - CHiFA - Issuu, n.d.-a). The project started in 1998 till 2005 where subsequent regeneration is taking place till the present times.

\subsubsection{Regenerative Parameters within the Project}

The start was with the first outstanding document of the city of Fez in 1975 named 'SchémaDirecteurd'Urbanisme.' was created by a team of trained consultants, talents architects and a local tea, trained in France in collaboration with UNESCO (el Harrouni\& el Hammoumi, 2017). It focused on developing a standard foundation for initiating the international campaign to protect the heritage of Fez in 1976 in Nairobi. The rehabilitation process has maintained these three guidelines to improve the entire Medina. Also, the program is consistent with the national policy guidelines where it followed a bottom-up approach, solving the root issues and not focus on topics such as the polishing of facades (Radoine, 2019). Not only this, but the conservation program in Fez also required the acquisition of adequate tools and extensive knowledge for its implementation through the implementation of planning tools ranging from(Urban Conservation of FezMedina, 2008),

- $\quad$ Financial where the UNESCO donated vast sums for the conservation program and the Moroccan government also provided fund for the process.

- Institutional in terms of being following entities responsible for actively monitoring and the conservation program implementation; the regional municipal council in Fez and the interior Ministry as well as skilled architects (el Harrouni\& el Hammoumi, 2017)

- $\quad$ Technical through deploying professionals from several disciplines who showed great interest in supporting heritage development as well o ADER-Fez (an extensive network of professionals including, researchers, architects, engineers, environmentalists, technicians, professors, economists, sociologists, and historians) who generated new ideas and provided solutions and are an integral participant in the conservation strategy of Fez.

The conservation program constitutes a multi-pronged approach with a vision to revitalize Fez and develop its economy, infrastructure, and social condition. First, physical conservation included the creation of themed tourist routes as referred in the below figure (4-4) and major city gates where mapping system with 700 signs offered a multilingual guide that defined six tourism circuits and guided visitors to them through the streets of the Medina. This offered an opportunity to provide tourism amenities which was redeemed in the restoration of three historic gardens, two public spaces including a bus parking lot at the city Gate and a Heritage Center in a restored building as well as other historic buildings and gates as in figures(4-5) and (4-6)(Case Studies in Heritage Regeneration by Cultural Heritage Finance Alliance - CHiFA - Issuu, 2021).

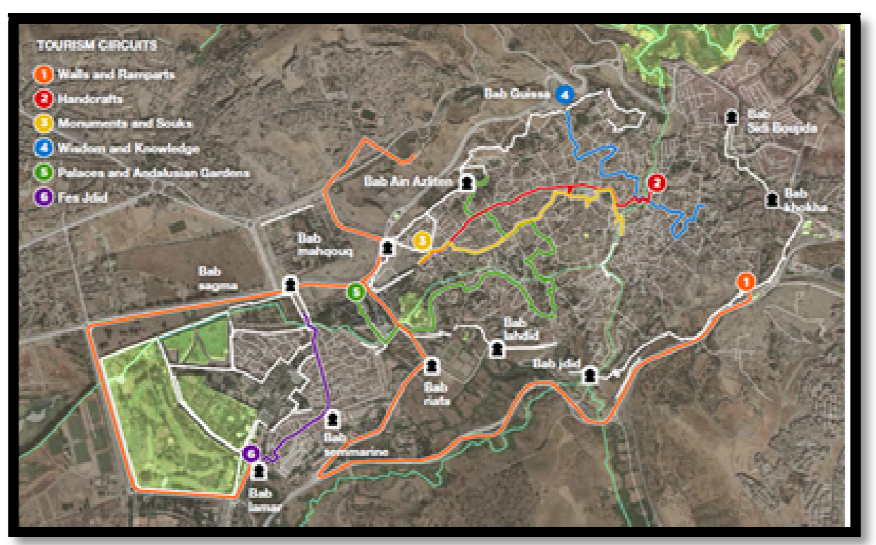

Figure 6: Aerial View of the Medina Showing Contemporary Themed Tourist Routes and Major City Gates Where the Visitor Might Choose to Take A 'Castles and Gardens,' A 'Crafts' Or A 'Walls and Fortresses' Tour Source: (Case Studies inHeritage Regeneration by Cultural Heritage Finance Alliance - Chifa - Issuu, 2021)

Moreover, the conservation program included mitigation of environmental pollution through solid waste management and chemical mitigation where the by-products of growth and development of the craft workshop near the residential zones of Fez which posed a significant threat to the health of the residents and water safety from the dying process and tanning for chemical and leather waste in the artisan manufacturing of Fez were sources of pollution to the city. On a social level, the local inhabitants gained technical skills and learned traditional employment and future maintenance methods while restoring their homes (Khalloufi et al., 2020). After rehabilitating one unit, others will observe and follow suit. Residential improvement was consistent with infrastructure development. These constituted improving the telephone and electricity grid, upgrading the sewage and water network, and developing nurseries and schools into the Fez improvement. In fact, Fez's design in the pedestrian environment city is structured with the absence of cars where streets were restrictive to emergency vehicles and engineering routes through the stairs enabled access to all corners within $100 \mathrm{~m}$, thus improving safety and security for all residents and visitors in Medina(Vatan\&Belcadi, 2019, The Medina of Fez: Analysis of a Superb Compact Town - Not Only About Architecture: Art, Land, Climate, 2011). In Medina of Fez, leisure, life, and work are integrated, implying that you live within the proximity of your social activities and employment. 
This helps in minimizing the travel distances, making it unnecessary to use cars, thus improving quality of life on several levels.

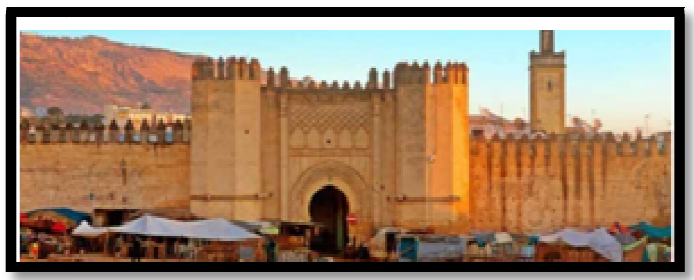

Figure 7: Bab Mahrouk Gate Where the Gateway Was Restored by a Private Bank after the World Bank-Funded Restoration Campaign Began

Source: Regeneration by Cultural Heritage Finance Alliance - Chifa - Issuu, 2021)

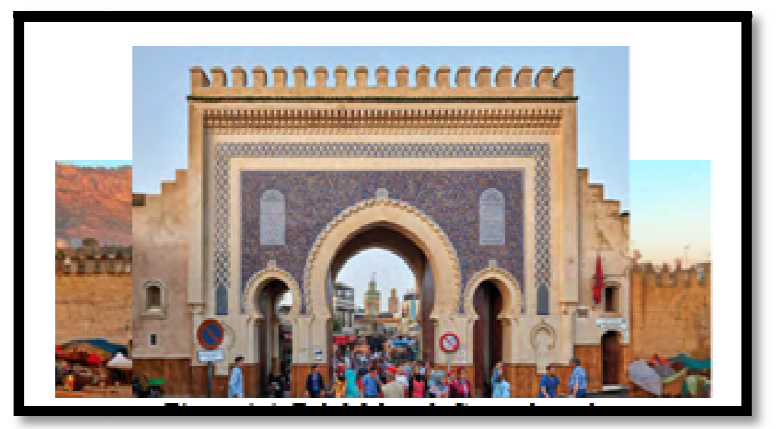

Figure 8.Restored Bab BouJeloud or Blue Gate

Source: (Case Studies in Heritage Regeneration by Cultural Heritage Finance Alliance - CHiFA - Issuu, 2021.)

\subsubsection{Complying with SDG's (Sustainable Development Goals)}

The complex fabric of Fez provides an example of the potential of urban regeneration while prioritizing the lives of the inhabitant (Demerdash-Fatemi, 2019). The citizenry's engagement capitalized and invigorated Medina's main assets, including the communities and their unique traditions and histories. The World Bank loans foster investment. Private investment also encouraged the protection of thirty-three historic buildings transformed into hotels and boutiques (Demerdash-Fatemi, 2019). International donors and other foundations rehabilitated more sites and buildings, preserving two public fountains and two significant monuments. The conservation process valued parallel investment from outside partners at $\$ 42.9$ million, three times more than the World Bank loans. The Moroccan government proceeded with investment in tourism and residential buildings where 132 workshops or housing units were rehabilitated with matching grants to their owners and another 107 communal spaces' interventions with resident participation. In association with the neighbor's, the conservation team consolidated 56 collapsing housesand repaired several pedestrian streets(Case Studies in Heritage Regeneration by Cultural Heritage Finance Alliance - CHiFA - Issuu, 2021).

Economically, though the World Bank investment in Medina is regarded as an effective demonstration of the best practice for incorporating heritage in development, the 2006 World Bank Implementation Completion and Results review can describe its immediate success. Compared to the expected economic effect of the project and the high Economic rate of return, the final report tally was disappointing where analysts claimed that over-optimistic assumptions unmet the project value leading to unrealistic high expectations. The reduced percentage of residents whose housing conditions were advanced through conservation was for material concern. The original goals of the initiatives were never achieved due to bureaucratic roadblocks that interfered with the completion of the pollution mitigation and sanitation improvement (Radoine\&Aomorali, 2019). As initially proposed in the strategic plan, the public-private partnership did not materialize and aborted the parking lot. Competition over the building's ownership slowed the conservation process of the buildings significantly when residents are displaced to create more spaces for infrastructure development. Although the project elements were successful, they were not as successful as the projection made during the negotiation and planning phase(Case Studies in Heritage Regeneration by Cultural Heritage Finance Alliance - CHiFA - Issuu, 2021).

\subsection{Discussion and Conclusion}

The conservation program has succeeded in many areas in the afore mentioned case studies. This program has made Mexico City and Fez some historic cities where conservation projects have been a success. The strengths provided by the city's cultural and historic profile as well as the effects of the exerts of the modern challenges has made the place a strong pivot for the application of the revitalization and conservation process. The area of Fez and Mexico City acquired unprecedented expertise as to the number of disciplines involved and the international and national institutions involved in the program. It is the intricacy and difficulty of the historic Mexico City and Fez that overwhelms professionals. Therefore, the problem of thoroughly solving such a site's challenges might encourage future generations on the relevance and genius of modeling and long-term crafting of historic cities. Lack of case study research on this rehabilitation project, internationally or nationally, develops varied images among researchers, politicians, and professionals. Although in the case of Medina of Fez, the success was limited to negotiation and planning phase due to material reasons, and competition over ownership, yet the practices implemented support it being a good practice of regenerative development example. The 
following table summarizes the actions that took place economically, socially, and cultural and socially as a guidance for actions for regenerative acts in regenerative sites.

\begin{tabular}{|c|c|c|}
\hline $\begin{array}{l}\text { Actions/ Case } \\
\text { Study }\end{array}$ & $\begin{array}{c}\text { Case Study of Medina of Fez, } \\
\text { Morocco }\end{array}$ & Case Study of Historic Center in Mexico City \\
\hline $\begin{array}{l}\text { Actions that } \\
\text { support economy }\end{array}$ & $\begin{array}{l}\text { - UNESCO training local } \\
\text { expertise } \\
\text { UNESCO provides fund for } \\
\text { the conservation program } \\
\text { Mapping system with } 700 \\
\text { signs offered a multilingual } \\
\text { guide that defined six } \\
\text { Tourism circuits and } \\
\text { guided visitors to them } \\
\text { through the streets of the } \\
\text { Medina } \\
\text { As a result, provision of } \\
\text { tourism amenities }\end{array}$ & $\begin{array}{l}\text { - } \text { New private businesses established } \\
\text { - Increased job opportunities created } \\
\text { through permanent business, and } \\
\text { works undertaken } \\
\text { - Micro-loans for inhabitants } \\
\text { - Creation of cultural, entertainment, } \\
\text { technology, and commercial corridors } \\
\text { which aimed to attract new activities } \\
\text { and businesses within those sectors. } \\
\text { Two phases of street rehabilitation, } \\
\text { made several purchases along the } \\
\text { developed avenues and streets, and } \\
\text { identified purchase areas based on } \\
\text { price and location } \\
\text { Creation of new businesses and jobs in } \\
\text { technology, commerce, hospitality, and } \\
\text { entertainment led to considerable } \\
\text { growth in property value }\end{array}$ \\
\hline $\begin{array}{l}\text { Actions that } \\
\text { support social and } \\
\text { cultural activities }\end{array}$ & $\begin{array}{l}\text { - Improve housing } \\
\text { - } \quad \text { Improve traffic circulation } \\
\text { Restoration of three } \\
\text { historic gardens, two public } \\
\text { spaces including a bus } \\
\text { parking lot at the city Gate } \\
\text { and a Heritage Center in a } \\
\text { restored building as a } \\
\text { revenue of tourism } \\
\text { amenities. } \\
\text { Locals gained technical } \\
\text { skills and learned } \\
\text { traditional employment } \\
\text { and future maintenance } \\
\text { methods while restoring } \\
\text { their homes } \\
\text { Developing nurseries and } \\
\text { schools into the Fez } \\
\text { improvement }\end{array}$ & $\begin{array}{l}\text { - Hundreds of buildings restored, and } \\
\text { public spaces and streets upgraded as } \\
\text { a revenue for new businesses } \\
\text { Improvement in life quality with new } \\
\text { public events, residents and tourism, } \\
\text { and the return of the previously } \\
\text { abandoned university department and } \\
\text { government offices. } \\
\text { - Public safety improvement } \\
\text { - Repaired sidewalks, relocation of } \\
\text { street vendors, new buried fiber optic } \\
\text { cables, and pedestrianizing streets. } \\
\text { Cultural activities and public events to } \\
\text { attract visitors } \\
\text { Improved public transportation and } \\
\text { the establishment of bicycle lanes. } \\
\text { Restoration of monuments and public } \\
\text { spaces } \\
\text { Complementary social programs } \\
\text { focused on family integration, } \\
\text { homelessness, education, public safety, } \\
\text { and health. } \\
\text { Minimal residential displacement }\end{array}$ \\
\hline $\begin{array}{l}\text { Actions that } \\
\text { support } \\
\text { environmental } \\
\text { benefits }\end{array}$ & 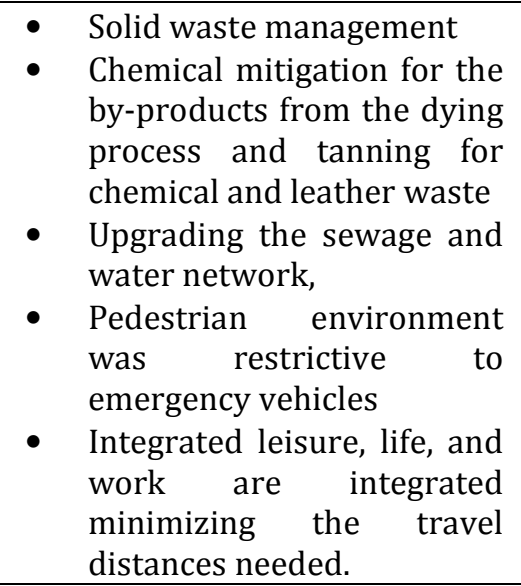 & $\begin{array}{l}\text { - Improvement of infrastructure and } \\
\text { building works } \\
\text { - Pedestrianization of streets } \\
\text { Provision of electronic monitoring } \\
\text { equipment }\end{array}$ \\
\hline
\end{tabular}

Table1: Comparative Analysis of Actions That Support SDG's (Sustainable Development Goals) in

Both Case Studies Analyzed-Source: Authors 
Thus, these case study presents the rehabilitation and conservation projects in Fez and Mexico City are considered of the best in the conservation field; making it a relevant case study that is suitable for consideration among professionals who intend to explore various challenges in the different cultural and heritages sites in the world.

\section{References}

i. Aalund, F. (2005). Islamic Cairo: Report on the ICOMOS reactive monitoring mission to World Heritage Sites. Paris.

ii. El Harrouni, K., \& el Hammoumi, A. (2017). Islamic heritage architecture analysis and restoration of rascherratine in fez, morocco. International Journal of Heritage Architecture: Studies, Repairs and Maintenance, 1(3), 401-410. https://doi.org/10.2495/HA-V1-N3-401-410

iii. Case Studies in Heritage Regeneration by Cultural Heritage Finance Alliance - CHiFA - issue. (2021Retrieved October 24, 2021, from https://issuu.com/bonnieburnham/docs/case_studies_in_hertage_regeneration

iv. Demerdash-Fatemi, N. (2019). The riad's resurgence: Questioning the historical legacy and neocolonial currency of the Moroccan courtyard house. In Neocolonialism and Built Heritage. Routledge. (pp. 217-235)

v. Guilbaud, M. N., delPilar Ortega-Larrocea, M., Cram, S., \& de Vries, B. V. W. (2021). Xitle Volcano Geoheritage, Mexico City: Raising Awareness of Natural Hazards and Environmental Sustainability in Active Volcanic Areas. Geoheritage, 13(1), 1-27.

vi. Historic Center of Mexico City, Mexico - Issuu. (2021). Retrieved October 24, 2021, from https://issuu.com/bonnieburnham/docs/case_studies_in_hertage_regeneration/s/12042322

vii. Liu, T., Butler, R. J., \& Zhang, C. (2019). Evaluation of public perceptions of authenticity of urban heritage under the conservation paradigm of Historic Urban Landscape-a case study of the Five Avenues Historic District in Tianjin, China. Journal of Architectural Conservation, 25(3), 228-251.

viii. Mang, P., \& Reed, B. (2012).Regenerative Development regenerative development and Design. Encyclopedia of Sustainability Science and Technology, 8855-8879. https://doi.org/10.1007/978-1-4419-0851-3_303

ix. Shady Attia Regenerative and Positive Impact Architecture Learning from Case Studies. (2018). http://www.springer.com/series/8903

x. The Medina of Fez: Analysis of a Superb Compact Town - Not Only About Architecture: Art, Land, Climate. (n.d.). Retrieved October 24, 2021, from https://www.patriciasendin.com/2011/09/medina-of-fez-analysis-ofsuperb.html

xi. Turner, C. \& Frankel, M. (2008). Energy performance of LEED for New Construction Buildings, Final Report. Washington: US Green Building Council.

xii. Urban Conservation of Fez-Medina. (2008). https://www.globalurban.org/GUDMag08Vol4Iss1/Radoine.htm

xiii. Williams, K.; Burton, E.; Jenks, M., (2000). Achieving sustainable urban form, Routledge, London. 